nezaradilo sa do väzenského slangu, mohlo vel'mi rýchlo zaniknút' (príp. zanikol len argotický význam slova).

Analýza asi 400 špecifikých lexikálnych jednotiek používaných vo väzenskom prostredí ukazuje, že sociálna, ale aj priestorová akčnost' väzenskej reči je výrazne obmedzená, a preto je azda aj najtypickejším predstavitel'om fakultatívnych slangov. Jeho komunikačná potencia je vel'mi vysoká vo svojom vlastnom prirodzenom prostredí, no naopak, smerom navonok, je vel'mi nízka (podobne je to aj v prípade argotu). Slangizmy používané vo väzenskej reči sú exkluzívnymi vyjadrovacími prostriedkami väzenskej subkultúry - ich exkluzivita sa prejavuje v rovine jednotlivých vecnoobsahových okruhov slov, a tie sa v iných skupinách slangu nevyskytujú, resp. vyskytujú sa iba okrajovo ako dôsledok prieniku lexiky väzenského slangu Vel'ká čast' slangizmov priamo súvisí s výkonom trestu, a teda je situačne a komunikačne viazaná na väzenské spoločenstvo; iba okrajovo môžeme uvažovat' infiltrácii daktorých prvkov z väzenského slangu do komunikačnej sféry malých sociálnych skupín. V tejto charakteristike sa teda skrýva odpoved' na apriórne, no neadekvátne zaradenie väzenského sociolektu k argotu. Lexikálne prvky tohto sociolektu vyvolávajú z hl'adiska nezainteresovaného príjemcu, ktorý nie je (nebol) príslušníkom väzenského spoločenstva, prirodzenú jazykovokomunikačnú entropiu. Jej dôsledok preto v chápaní „,vonkajšieho“ spoločenstva môže posúvat' podstatu tohoto sekundárneho či faultatívneho slangu do roviny argotu.

\title{
LITERATÚRA
}

1. Hochel, B.: Slovník slovenského slangu. Bratislava: Hevi 1993. $188 \mathrm{~s}$.

2. Odaloš, P.: Sociolekty v basketbalovom a penitenciárnom prostredí. Banská Bystrica : Pedagogická fakulta UMB, 1997. 92 s. ISBN 80-8055-031-X.

3. Ondrus, P.: Sociálne nárečia na Slovensku. Zv. 1. Argot slovenských detí. Bratislava : SPN 1977. $248 \mathrm{~s}$.

4. Slovník nespisovné češtiny. Ed. J. Hugo. Praha : Maxdorf, 2009. 501 s. ISBN 978-807345-198-1.

5. Slovnik súčasného slovenského jazyka. Zv. 1. A - G. Ed. K. Buzássyová, A. Jarošová. Bratislava : Veda, 2006. 1134 s. ISBN 80-224-0932-4.

Стаття надійшла 09.01.2016 року

УДК 811.161.2’367

Ніна Грозян

(Сімферополь, Україна)

\section{КЛАСИФІКАЦІЙНІ ОЗНАКИ ДРУГОРЯДНИХ ЧЛЕНІВ РЕЧЕННЯ}

Статтю присвячено з'ясуванню класифікаційних ознак другорядних членів речення в річищі сучасних наукових досліджень. Окреслено категорію членів речення 
як багатоаспектного явища, проаналізовано досліднищькі підходи до вивчення членів речення в традиційному $i$ новітньому мовознавстві. Обгрунтовано дієвість функиійного підходу, за яким мінімальні синтаксичні одиниці аналізують на тлі формально-синтаксичної, семантико-синтаксичної та комунікативної структур речення. Зауважено, шзо ичілісне дослідження членів речення трунтується на їхній формальній, семантичній $i$ комунікативній диференціації, а тому визначення диференційних ознак мінімальних синтаксичних одинищь повинно трунтуватися на врахуванні кореляцій традиційних другорядних членів речення з їхніми формальносинтаксичними, семантико-синтаксичними та комунікативними відповідниками.

Ключові слова: член речення; мінімальна синтаксична одиниця; синтаксема; комунікатема; формально-синтаксичний ярус; семантико-синтаксичний ярус; комунікативний ярус; функційна класифікація.

\section{Грозян Н. Классификационные признаки второстепенных членов предложсния.}

Статья посвящена выяснению классификационных признаков второстепенных членов предложения в русле современных научных исследований. Определена категория членов предложения как многоаспектного явления, проанализированы исследовательские подходы к изучению членов предложения в традиционном $u$ новейшем языкознании. Обоснована действенность функционального подхода, согласно которому минимальные синтаксические единицы анализируются на фоне формально-синтаксической, семантико-синтаксической и коммуникативной структур предложения. Сделан вывод, что целостное исследование членов предложения основывается на их формальной, семантической и коммуникативной дифференциичии, а поэтому определение дифференциальных признаков минимальных синтаксических единиц должно учитывать корреляции традиционных второстепенных членов предложения с их формально-синтаксическими, семантикосинтаксическими и коммуникативными аналогами.

Ключевые слова: член предложения; минимальная синтаксическая единица; синтаксема; коммуникатема; формально-синтаксический ярус; семантикосинтаксический ярус; коммуникативный ярус; функциональная классификация.

\section{Grozian N. Classification features of the secondary parts of sentence.}

The article is devoted to clarifying the differential features of the secondary parts of sentence in line with modern scientific research. The category of the sentence parts as a multidimensional phenomenon is defined, research approaches to the study of the sentence in the traditional and contemporary linguistics are analyzed. The efficiency of functional approach by which minimal syntactic units are analyzed against the background of formal syntactic, semantic and syntactic as well as communicative sentence structures is proved. It is noted that a holistic study of minimal syntactic units is based on their formal, semantic and communicative differentiation, therefore determining the differential signs of minimal syntactic units should be based on consideration of traditional secondary parts of the sentence with their formal and syntactic, semantic and syntactic as well as communicative counterparts. The following differential features of the secondary parts of sentence are determined: the role of formal and syntactic structure of sentences; correlation with actual parts of sentence; means of expression; position in formal and syntactic structure of sentence; kind of syntactic context; ratio with syntaxema; kind of semantic and syntactic relationships; positional fixation in the actual division, the ratio with communicative unites. 
Keywords: sentence part; minimal syntactic unit; syntaxeme; communicative unit; formal syntactic tier, semantic and syntactic tier, communicative tier, functional classification.

Визнання багатоаспектності речення актуалізує проблему його сегментації - поділу на члени речення (мінімальні синтаксичні одиниці, компоненти речення, поширювачі, синтаксеми тощо). Синтаксична традиція i новітні наукові концепції по-різному класифікують члени речення, що зумовлене неоднаковими підходами до з'ясування їхньої специфіки і статусу, визначення принципів диференціації тощо.

На сьогодні в лінгвістиці виконано низку вагомих наукових студій, що презентують різні підходи до вивчення членів речення. Теоретичне осмислення формально-синтаксичної структури речення представлене в працях В. В. Бабайцевої [1], В. А. Бєлошапкової [2], I. Р. Вихованця [4; 5], Н. В. Гуйванюк [8], А. П. Загнітка [10], Н. Л. Іваницької [12], М. В. Мірченка [15], К. Ф. Шульжука [17] та ін. Проблеми мінімальної семантико-синтаксичної одиниці досліджували I. Р. Вихованець [5], К. Г. Городенська [7], А. П. Загнітко [10], Г. О. Золотова [11], О. В. Кульбабська [13], О. Г. Межов [14] та ін., комунікативний аспект Т. Ф. Дацько [9], М. О. Вінтонів [6] та ін.

Попри таку потужну наукову запотребуваність, питання аналізу членів речення остаточно не розв'язане, оскільки на кожному етапі наукового пізнання 3' являються нові аспекти їх опису. Актуальність теми увиразнює наявність різноманітних, нерідко протилежних, концепцій i підходів, що стосуються місця аналізованих компонентів серед інших синтаксичних одиниць, їхньої типології, критеріїв розмежування, формальної, семантичної і комунікативної диференціації тощо. Погоджуємося 3 В. В. Бабайцевою, що члени речення - це фокус, який збирає все, а тому глибоке їх вивчення передбачає врахування всіх аспектів речення [1, с. 31].

Мета статті - 3’ясувати класифікаційні ознаки другорядних членів речення в річищі сучасних наукових досліджень. Досягненню поставленої мети сприятиме реалізація таких завдань: окреслити категорію членів речення як багатоаспектного явища; обгрунтувати дієвість функційного підходу, за яким мінімальні синтаксичні одиниці аналізують на тлі формально-синтаксичної, семантико-синтаксичної та комунікативної структур речення; умотивувати доцільність визначення диференційних ознак мінімальних синтаксичних одиниць на підставі кореляцій традиційних другорядних членів речення 3 їхніми формальносинтаксичними, семантико-синтаксичними та комунікативними відповідниками. 
Труднощі класифікації членів речення пов'язані з низкою обставин: 1) невизначеністю об' єкта класифікації (члени предикативної одиниці, члени речення, словоформи у їх співвідношенні з іншими компонентами); 2) можливістю різних принципів класифікації (характер відношень, форма вираження, структурна роль); 3 ) наявністю багатьох чинників розрізнення членів речення (морфологічна форма, лексичне наповнення, порядок слів) [16, с. 48-49].

Функційна концепція, що на сьогодні $\epsilon$ найбільш логічною й позбавленою недоліків традиційної класифікації, зумовила виокремлення двох рядів членів речення - формально-синтаксичних (власне-членів речення) і семантико-синтаксичних (синтаксем). Завдяки розвиткові теорії актуального членування комплексна схема диференціації членів речення була доповнена і їхніми комунікативно-позиційними характеристиками. Н. Л. Іваницька наголошує, що «практичне визначення члена речення грунтується на основі комплексу семантичних та формальних ознак 3 урахуванням комунікативного призначення речення та окремих його частин», а тому «обсяг поняття «член речення» дає змогу синтезувати всі аспекти: логіко-синтаксичний, структурно-синтаксичний і комунікативносинтаксичний» $[12$, с. 78]. I. Р. Вихованець акцентує на тому, що повний функційний синтаксис відповідної мови має охоплювати як семантичний синтаксис, так і комунікативний та формальний [5].

Члени речення постають своєрідними конденсаторами, що дають змогу доповнити раніше виявлені властивості складників речення новими властивостями, побаченими й описаними під іншим кутом зору, в аспекті нових синтаксичних напрямів [1, с. 32].

На сьогодні основними аспектами речення визнано формальносинтаксичний, семантико-синтаксичний та комунікативний. Формальносинтаксичний передбачає диференціацію власне-членів речення за типом синтаксичного зв' язку на головні і неголовні (або другорядні). Семантикосинтаксичний відображає предмети і явища позамовного світу та їхні відношення, а тому поділ синтаксем (семантико-синтаксичних членів речення) грунтується на семантико-синтаксичних відношеннях. У комунікативному аспекті сегментація на компоненти речення мотивована комунікативною метою, а тому вони корелюють із темою або ремою.

Основним критерієм визначення і розмежування членів речення $\epsilon$ ті відношення, у які вони вступають 3 іншими компонентами, тобто кореляції між: власне-членами речення (формально-синтаксичний аспект), синтаксемами (семантико-синтаксичний аспект), комунікатемами компонентами, які переважно кваліфіковані як тема i рема (комунікативний аспект).

Проблема визначення членів речення постала водночас iз виникненням синтаксичного підходу до аналізу лінгвістичних явищ. 
Члени речення виділяють із речення як його будівельні компоненти, що мають певну семантику. Підсумовуючи ознаки членів речення, виокремлені в процесі їхнього багатоаспектного вивчення в різні періоди, дослідники зазвичай розмежовують структурні та семантичні [1, с. 19-20; 10, с. 491-492].

Структурними ознаками, що репрезентують особливості й закономірності вираження членів речення і сигналізують про категорійну семантику останніх, називають: 1) участь у формуванні структурної схеми речення; 2) спосіб вираження членів речення; 3) форма підрядного прислівного синтаксичного зв'язку (узгодження, кореляція, керування, прилягання); 4) синтаксична позиція.

Семантичні властивості членів речення охоплюють: 1) логічні значення; 2) категорійні значення; 3) лексичні значення; 4) комунікативне навантаження; 5) семантико-синтаксичні відношення членів речення (атрибутивні, об' єктні, обставинні, суб' єктні, комплетивні) [1, с. 19-20; 10 , с. 491-492].

Цей перелік властивостей не $\epsilon$ вичерпним, він охоплює лише найсуттєвіші диференційні ознаки, жодна з яких не може бути єдиною для класифікації членів речення. Відомо, що спроби побудувати типологію на підставі якоїсь однієї ознаки не увінчались успіхом. Кваліфікація членів речення передбачає врахування усіх критеріїв. Наприклад, якщо в реченні Найнеобхініша наука - ие наука забувати непотрібне (Антисфен, упорядник Л. П. Олексієнко) брати до уваги лише структурні особливості (наука - ие наука), то семантичні конкретизатори - словоформи найнеобхідніша і забувати - будуть потрактовані як означення. Однак витлумачення членів речення як структурно-семантичних компонентів передбачає уведення семантичних конкретизаторів до складу головних членів: наука забувати - підмет, найнеобхідніша наука - присудок. До того ж присудок не може дублювати підмет, адже в комунікативному аспекті він найчастіше корелює з ремою, а тому повинен містити нову інформацію.

На нашу думку, цілісне дослідження членів речення повинно грунтуватися на їхній формальній, семантичній i комунікативній диференціації, а тому визначення диференційних ознак мінімальних синтаксичних одиниць повинно враховувати кореляції традиційних другорядних членів речення 3 їхніми формально-синтаксичними, семантико-синтаксичними та комунікативними відповідниками.

Класифікаційними ознаками другорядних членів речення (класифікаційний - стосується класифікації у 2 значенні як системи розподілу предметів, явищ або понять на класи, групи тощо за спільними ознаками, властивостями) [3, с. 432]) логічно вважати такі: 1) роль у формально-синтаксичній структурі речення; 2) кореляція із власне- 
членами речення; 3) засоби вираження; 4) позиція у формальносинтаксичній структурі речення; 5) різновид синтаксичного зв'язку; 6) співвідношення із синтаксемами; 7) різновид семантико-синтаксичних відношень; 8) позиційна закріпленість при актуальному членуванні, співвідношення $з$ комунікатемами.

Весь комплекс диференційних ознак у проекції на традиційні другорядні члени речення узагальнено у зведеній таблиці (див. табл. 1).

Таблиия 1

\section{Класифікаційні ознаки другорядних членів речення}

\begin{tabular}{|c|c|c|c|}
\hline & Додаток & Означення & Обставина \\
\hline 1 & $\begin{array}{c}\text { входить у формально- } \\
\text { синтаксичну структуру } \\
\text { речення як його } \\
\text { другорядний член }\end{array}$ & $\begin{array}{c}\text { входить у формально- } \\
\text { синтаксичну структуру } \\
\text { речення як його } \\
\text { другорядний член }\end{array}$ & $\begin{array}{c}\text { входить у формально- } \\
\text { синтаксичну структуру } \\
\text { речення як його } \\
\text { другорядний член }\end{array}$ \\
\hline 2 & $\begin{array}{c}\text { корелює з прислівним } \\
\text { керованим другорядним } \\
\text { членом речення, зрідка - } \\
\text { з об'єктним } \\
\text { детермінантом }\end{array}$ & $\begin{array}{c}\text { корелює з прислівним } \\
\text { узгодженим членом } \\
\text { речення (у типовому } \\
\text { вияві), прислівним } \\
\text { прилеглим членом } \\
\text { речення та з корелятом }\end{array}$ & $\begin{array}{c}\text { корелює з } \\
\text { детермінантними } \\
\text { членами речення } \\
\text { (фоновими локативним та } \\
\text { темпоральним; із } \\
\text { детермінантами } \\
\text { зумовленості } \\
\text { (причиновим, цільовим, } \\
\text { умовним, допустовим); } \\
\text { детермінантом із } \\
\text { характеризувальним } \\
\text { значенням } \\
\text { (атрибутивним, } \\
\text { уточнення / обмеження; } \\
\text { порівняння; сукупності / } \\
\text { роздільності); із } \\
\text { прислівним прилеглим } \\
\text { членом речення } 3 \\
\text { кількісним та } \\
\text { просторовим значеннями }\end{array}$ \\
\hline 3 & $\begin{array}{c}\text { у типових випадках } \\
\text { виражений іменником, } \\
\text { займенником }\end{array}$ & $\begin{array}{c}\text { у типових випадках } \\
\text { виражене прикметником, } \\
\text { числівником, } \\
\text { займенником, } \\
\text { дієприкметником }\end{array}$ & $\begin{array}{c}\text { виражена прислівником, } \\
\text { інфінітивом, } \\
\text { відмінковими та } \\
\text { прийменниково- } \\
\text { відмінковими формами } \\
\text { іменників }\end{array}$ \\
\hline 4 & $\begin{array}{c}\text { у типовому вияві стоїть } \\
\text { після опорного слова } \\
\text { (дієслова, прикметника, } \\
\text { дієприкметника, }\end{array}$ & $\begin{array}{c}\text { у типовому вияві стоїть } \\
\text { перед опорним словом } \\
\text { (іменником, } \\
\text { займенником) }\end{array}$ & $\begin{array}{c}\text { у типовому вияві } \\
\text { стоїть у постпозиції щодо } \\
\text { опорного слова (дієслова, } \\
\text { прикметника, }\end{array}$ \\
\hline
\end{tabular}




\begin{tabular}{|c|c|c|c|}
\hline & віддієслівного іменника) & & $\begin{array}{c}\text { дієприкметника), а також } \\
\text { у препозиції }\end{array}$ \\
\hline 5 & $\begin{array}{c}\text { поєднується з опорним } \\
\text { словом підрядним } \\
\text { прислівним } \\
\text { синтаксичним зв’язком у } \\
\text { формі керування }\end{array}$ & $\begin{array}{c}\text { поєднується з опорним } \\
\text { словом підрядним } \\
\text { прислівним } \\
\text { синтаксичним зв'язком у } \\
\text { формі узгодження або } \\
\text { кореляції }\end{array}$ & $\begin{array}{c}\text { поєднується з опорним } \\
\text { словом підрядним } \\
\text { прислівним } \\
\text { синтаксичним зв’язком у } \\
\text { формі прилягання }\end{array}$ \\
\hline 6 & $\begin{array}{c}\text { у семантико- } \\
\text { синтаксичній структурі } \\
\text { речення співвідноситься } \\
\text { із субстанціальними } \\
\text { об'єктною, суб'єктною, } \\
\text { адресатною, } \\
\text { інструментальною } \\
\text { синтаксемами }\end{array}$ & $\begin{array}{c}\text { у семантико- } \\
\text { синтаксичній структурі } \\
\text { речення співвідноситься } \\
\text { із вторинною } \\
\text { предикатною } \\
\text { атрибутивною } \\
\text { синтаксемою, } \\
\text { субстанціальною } \\
\text { суб’ єктною синтаксемою }\end{array}$ & $\begin{array}{c}\text { у семантико- } \\
\text { синтаксичній структурі } \\
\text { речення співвідноситься } \\
\text { iз субстанціальною } \\
\text { локативною } \\
\text { синтаксемою, } \\
\text { вторинними } \\
\text { предикатними } \\
\text { синтаксемами часу, } \\
\text { причини, умови, допусту, } \\
\text { порівняння; із вторинною } \\
\text { предикатною } \\
\text { атрибутивною } \\
\text { синтаксемою }\end{array}$ \\
\hline 7 & $\begin{array}{c}\text { виражає об’ єктні } \\
\text { семантико-синтаксичні } \\
\text { відношення }\end{array}$ & $\begin{array}{c}\text { виражає означальні } \\
\text { семантико-синтаксичні } \\
\text { відношення }\end{array}$ & $\begin{array}{c}\text { виражає обставинні } \\
\text { семантико-синтаксичні } \\
\text { відношення }\end{array}$ \\
\hline 8 & $\begin{array}{c}\text { не виявляє позиційної } \\
\text { закріпленості при } \\
\text { актуальному членуванні } \\
\text { речення, може бути } \\
\text { темою або ремою }\end{array}$ & $\begin{array}{c}\text { не виявляє позиційної } \\
\text { закріпленості при } \\
\text { актуальному членуванні } \\
\text { речення, може бути } \\
\text { темою або ремою }\end{array}$ & $\begin{array}{c}\text { не виявляє позиційної } \\
\text { закріпленості при } \\
\text { актуальному членуванні } \\
\text { речення, може бути } \\
\text { темою або ремою }\end{array}$ \\
\hline
\end{tabular}

Отже, функційний підхід, за яким мінімальні синтаксичні одиниці аналізують на тлі формально-синтаксичної, семантико-синтаксичної та комунікативної структур речення, $\epsilon$ найбільш дієвим. Визначення диференційних класифікаційних ознак мінімальних синтаксичних одиниць повинно грунтуватися на врахуванні кореляцій традиційних другорядних членів речення 3 їхніми формально-синтаксичними, семантико-синтаксичними та комунікативними відповідниками.

\section{СПИСОК ВИКОРИСТАНОЇ ЛІТЕРАТУРИ}

1. Бабайцева, В. В. Система членов предложения в современном русском языке / В. В. Бабайцева. - М. : Просвещение, 1988. - 159 с.

2. Белошапкова, В. А. Современный русский язык: Синтаксис / В. А. Белошапкова. - М. : Высш. шк., 1977. - 248 с.

3. Великий тлумачний словник сучасної української мови / [укл. і голов. ред. В. Т. Бусел]. - К. ; Ірпінь : ВТФ «Перун», 2003. - 1440 с. 
4. Вихованець, І. Р. Граматика української мови. Синтаксис : [підручник] / І. Р. Вихованець. - К. : Либідь, 1993. - 368 с.

5. Вихованець, І. Р. Нариси 3 функціонального синтаксису української мови : [монографія] / I. Р. Вихованець. - К. : Наук. думка, 1992. - 222 с.

6. Вінтонів, М.О. Актуальне членування речення і тексту: формальні та функційні вияви : [монографія] / М. О. Вінтонів. - Донецьк : ДонНУ, 2013. 327 c.

7. Городенська, К.Г. Деривація синтаксичних одиниць : [монографія] / К. Г. Городенська. - К. : Наук. думка, 1991. - 192 с.

8. Гуйванюк, Н. В. Формально-семантичні співвідношення в системі синтаксичних одиниць : [монографія] / Н. В. Гуйванюк. - Чернівці : Рута, 1999. $-336 \mathrm{c}$.

9. Дацко, Т. Ф. Коммуникативная структура простого предложения в английском и русском языках : дисс. ... докт. филол. наук : 10.02.19 / Дацко Татьяна Федоровна. - Краснодар, 2006. - 337 с.

10. Загнітко, А. П. Теоретична граматика сучасної української мови. Морфологія. Синтаксис / А. П. Загнітко. - Донецьк : ТОВ «ВКФ «БАО», 2011. - 992 с.

11.Золотова, Г.А. Синтаксический словарь. Репертуар элементарных единиц руського синтаксиса / Г. А. Золотова. - М. : Наука, 1988. - 440 с.

12. Іваницька, Н. Л. Теоретичний синтаксис української мови. Частина перша / Н. Л. Іваницька. - Вінниця : ВДПУ ім. М. Коцюбинського, 2002. - 169 с.

13. Кульбабська, О. В. Вторинна предикація у простому реченні : [монографія] / О. В. Кульбабська. - Чернівці : Чернів. нац. ун-т, 2011. - 672 с.

14. Межов, О.Г. Типологія мінімальних семантико-синтаксичних одиниць : [монографія] / О. Г. Межов. - Луцьк : Волин. нац. ун-т ім. Лесі Українки, 2012. $-464 \mathrm{c}$.

15. Мірченко, М. В. Структура синтаксичних категорій : [монографія] / М. В. Мірченко. - Вид. 2-ге, переробл. - Луцьк : Ред.-вид. відд. «Вежа» ВДУ ім. Лесі Українки, 2004. - 393 с.

16. Сиротинина, О. Б. Лекции по синтаксису русского языка / О. Б. Сиротинина. М. : Высшая школа, 1980. - 141 с.

17. Шульжук, К. Ф. Синтаксис української мови : [підручник] / К. Ф. Шульжук. К. : Видавничий центр «Академія», 2004. - 408 с.

Стаття надійшла 20.08.2016 року

УДК 811.161.2’367.622’366.54

Василь Денисюк

(Умань, Украӥна)

\section{ВАРІАНТНІ ФОРМИ ДАВАЛЬНОГО ВІДМІНКА ІМЕННИКІВ ЯК МОВНИЙ ЛАКМУС ПИСЕМНИХ ПАМ'ЯТОК ХVII-XVIII ст.}

У статті проаналізовано функиіонування давального відмінка іменників чоловічого роду II відміни в літописних пам'ятках у контексті розвитку украӥнської літературної мови XVII-XVIII cm. 3'ясовано, щуо система іменника, засвідчена в 